\title{
Female Teachers' Perceptions of Teaching Culture in EFL Classrooms at a Saudi University
}

\author{
Bayan Al-Hashemi Al-Amir ${ }^{1}$ \\ ${ }^{1}$ English Language Institute, King Abdulaziz University, Kingdom of Saudi Arabia \\ Correspondence: Bayan Al-Hashemi Al-Amir, English Language Institute, King Abdulaziz University, Kingdom \\ of Saudi Arabia. E-mail: Bayan.AlHashemi.1413@gmail.com
}

Received: March 1, 2017 Accepted: May 20, 2017 Online Published: May 26, 2017

doi: 10.5539/elt.v10n6p28 URL: http://doi.org/10.5539/elt.v10n6p28

\begin{abstract}
In the literature of second language teaching and learning, culture and language have always been assumed to be interdependent. Their interdependence comes from the fact that language is not a code free from culture, but an embodiment of it. However, there is still a need, from the part of teachers, to realize the importance of integrating culture with language study. Using a three- Points Likert scale questionnaire, the current study aims at investigating teachers' perceptions of culture teaching in English as a foreign language classrooms at the University of Jeddah. Moreover, it aims at discovering the type of cultural competence teachers seek to promote; whether it is intercultural or multicultural. The results show that female teachers support the study of the target culture. Furthermore, the results indicate that teachers' perceptions lean more towards promoting multicultural competence instead of intercultural one.
\end{abstract}

Keywords: teachers' perceptions, study of culture, itercultral competence, multicultural competence, EFL classrooms, Saudi Arabia

\section{Introduction}

It has long been assumed that culture is an integral element in the interaction between language and thoughts (Brown, 2000). This description implies that culture and language are two interdependent concepts, and that their interdependence comes from the fact that language is not a code free from culture (Kramsch, 1998, cited in Eldin, 2015), but an embodiment of it (Gonen \& Saglam, 2012). Once language and culture get separated from each other, either one of them will lose its significance (Brown, 2002).

In characterization of the nature of language and culture, Damen (1987) pointed out that culture is learnable as much as it is acquirable. Therefore, although it has been assumed that second language learning is an intercultural act (Sercu \& Bandura, 2005), the acquisition of a given language does not necessarily lead to the peripheral acquisition of its culture. Accordingly, claiming that the incorporation of culture into language classrooms is pointless denies the complex nature of culture and language learning (Lessard-Cloouston, 1997, cited in Thanasoulas, 2001) especially in EFL contexts, where language is not acquired in natural settings.

\subsection{Target Culture in EFL Classrooms}

According to Thanasoulas (2001), language learning includes more than linguistic and grammatical competence; it is also comprised of communicative competence and language proficiency. Communicative competence refers to individuals' ability to communicate with people of different social and cultural identities. In order for students to obtain such competence, they need to establish a shared understanding between them and people from different cultural backgrounds. This shared framework has been referred to as intercultural competence (Byram, Gribkova \& Starkey, 2002). According to Samovar, Porter, \& Jain (1981, cited in Thanasoulas, 2001), communicative competence and culture cannot be separated from each other because culture is the base for all types of communication. It determines the rules that govern who talks to whom, the content of the message and manner in which a message is sent. Therefore, students in both foreign and second language classrooms need to be exposed to the target culture in order to develop such communicative competence.

EFL classrooms are different than the English as a Second Language (ESL) ones in the sense that when learning a foreign language, students get connected to a world that is culturally distinct and different from the one they live in. In such contexts, culture-related issues should be intentionally addressed in order to demonstrate how 
language is used in meaningful contexts. Shukri (2014), for example, illustrated that the use of cultural activities helps in promoting students' pragmatic awareness and guiding the way they construct language and the way they interpret discoursal meanings. Therefore, the need for a culturally oriented instruction in EFL classrooms is stronger than in other contexts. However, it is still important to examine how the culture of the target language, English here, is viewed before deciding which cultural elements are to be integrated.

\subsection{Essentialism and English as a Lingua Franca}

Culture has been viewed from different perspectives: one of them is the essentialist view. The essentialist view is perceived, by Grillo (2003), as describing culture by presenting the most essential characteristics of its people. These characteristics are stable; and they differentiate a group of people from others. Such view implies that each culture is associated to a specific language and a specific country. However, the current status of English makes it difficult to view culture from a perspective as simple as that.

In contrast to the essentialist view of culture, Al-Fahadi (2012) argues for the autonomy of English and its independence of any specific culture for several reasons. According to him, English nowadays has become a lingua-franca. Therefore, it cannot be neither attributed to countries, such as the UK or the USA, nor associated with the norms and values of a given group of people. Instead, he claims that with the current state of globalization, teachers are required to promote multicultural competence in their EFL classrooms. Accordingly, it is important to differentiate between intercultural and multicultural competences in language classrooms based on how each one is used in research.

According to Sercu \& Bandura (2005), intercultural competence is defined as promoting students' knowledge and familiarity with those elements of the foreign culture which are present in the textbook, neglecting the less visible elements. A classroom where language is taught with an intercultural competence is one that helps students acquire both, linguistic knowledge and intercultural competence (Byram, Gribkova \& Starkey, 2002). Multicultural competence, on the other hand, is viewed as one that represents a variety of cultures, not just the target one (Al-Fahadi, 2012).

\subsection{Cultural Identification and Creative Performance}

Cultural identification and creative performance, as described by Chiu \& Cheng (2007), are two of the social consequences of having two cultural representations in one setting. The former refers to one's identification of his own culture as the favorite, whereas the latter means assigning the two cultures the same rank and emphasizing their creative distinctiveness. In EFL classrooms, where culture-teaching is an essential element, students and non-native teachers are in a position where they come face to face with two distinct cultures, the target culture and their native one.

Among the many participants in the foreign language teaching and learning experience, this study focuses on EFL teachers. Shukri (2014) shed light on teachers' role in the process of culture teaching and indicated that language teachers are not only language instructors, they function as mediators in the process of transmitting the target culture to students. The following part reviews some of the previous studies conducted on how teachers perceive the integration of culture into EFL classrooms.

\subsection{Literature Review on Teachers' Perceptions of Teaching Culture}

In a broad investigation of teachers' role in promoting cultural competence in foreign language classrooms, Sercu \& Bandura (2005) pointed out that although the education language teachers receive, constitutes a crucial element in such process, it is up to the individual teacher to introduce culture in their students in their lessons. As a result, due to the important role culture plays in FL classrooms, teachers are expected to facilitate the acquisition of cultural competence along with the acquisition of language.

In a comparative study conducted by Sercu and Bandura (2005), a questionnaire was used to investigate teachers' perceptions towards the incorporation of intercultural competence in EFL classrooms. Teachers who participated in the study were from seven different countries: Bulgaria, Mexico, Spain, Belgium, Poland, Greece and Sweden. They were asked whether they believed cultural competence should be taught in their classrooms and whether it has positive impacts on students' performance or not. The results showed that the teacher participants supported the concept of cultural tolerance. However, their realization of culture teaching was more as passing on information about how people communicate in the target language than promoting intercultural competence. To them, culture teaching means providing students with information about daily life, rather than information about history, political issues and culture.

In a study conducted by Gonen and Saglam (2012), teachers with different educational backgrounds were put under examination in order to investigate their perceptions towards the incorporation of culture into Turkish EFL 
classrooms. The data gathered through some questionnaires and a group of interviews reveal that all the teachers, regardless of their different educational backgrounds, are well aware of the importance of culture in language classrooms. Thus, the researchers suggested that more efforts should be put in preparing EFL teachers on how to teach culture and in providing them with materials necessary for this purpose.

When investigating Saudi EFL teachers' perceptions towards the cultural content of language text-books, Al-Fahadi (2006, cited in Al-Fahadi, 2012) found that although Saudi EFL teachers are affected by the Islam-phobic events, they were not against the utilization of the norm, beliefs and values of the target culture. The current study investigates Saudi female EFL teachers' perceptions towards teaching the target culture in general, not only based on the cultural contents in English textbooks. It aims at answering the following two research questions:

\subsection{Research Questions}

1) Do female non-native teachers of English support the teaching of Foreign Language (FL) culture in EFL classrooms?

2) What kind of cultural competence do EFL teachers seek to promote? Intercultural or multicultural competence?

\section{Methodology}

\subsection{Participants}

The questionnaire was sent to the entire female EFL teachers at the University of Jeddah. Nevertheless, only 25 teachers responded to the questionnaire representing around $41.6 \%$ of the whole population. To ensure the accuracy of the results, participants were required to indicate whether they are native speakers or not, for the study only targetted those who were non-natives.

\subsection{Data Collection and Analysis}

Since the use of questionnaires is one of the dominant ways of collecting data related to perceptions and attitudes (Mackey \& Gass, 2005), the main tool in this study is a questionnaire adapted from Gonen and Saglam's (2012) study. It is of three-point Likert Scale (Agree, neutral, disagree). The first part of the questionnaire investigates teachers' perceptions towards culture teaching in EFL classrooms. However, another part was added to investigate teachers' perceptions towards the kind of cultural competence that should be prompted in class; whether it is an intercultural competence or a multicultural one. The data gathered from the questionnaire were analyzed descriptively to find the frequencies and the percentages of the responses of the teacher participants.

\subsection{Procedures}

An ethical approval letter to conduct the study and send the online questionnaire to EFL teachers was requested from the Vice-Dean of the ELI women's campus at the University of Jeddah. The online form required the participants to sign an informed consent before they got to the questionnaire items. The results were then analyzed descriptively. Based on the findings of the study, a number of conclusions and recommendations were drawn.

\section{Results and Discussion}

\subsection{Question 1}

Do non-native teachers of English support the teaching of FL culture in EFL classrooms?

The first fifteen items of the questionnaire aimed at answering this question. They aimed at investigating teachers' perceptions towards the study of culture, its aspects and effects. The following Table summarizes the results.

Table 1. Teachers' perceptions of the study of culture

\begin{tabular}{llll}
\hline Items of the Questionnaire & $\mathrm{N}$ & $\mathrm{N}$ & $\%$ \\
\hline 1. In EFL classrooms, where I teach now, teaching culture is as important as teaching & Agree. & 14 & 56 \\
\cline { 2 - 4 } English. & Neutral. & 6 & 24 \\
\cline { 2 - 4 } & Disagree. & 5 & 20 \\
\hline 2. It is impossible to teach the foreign language and the foreign culture in an integrated & Agree. & 4 & 16 \\
\hline
\end{tabular}




\begin{tabular}{|c|c|c|c|}
\hline \multirow[t]{2}{*}{ way. } & Neutral. & 5 & 20 \\
\hline & Disagree. & 16 & 64 \\
\hline \multirow[t]{3}{*}{ 3. The more students know about the foreign culture, the more tolerant they are. } & Agree. & 15 & 60 \\
\hline & Neutral. & 10 & 40 \\
\hline & Disagree. & 0 & 0 \\
\hline \multirow{3}{*}{$\begin{array}{l}\text { 4. When speakers of different languages meet, misunderstandings arise equally often } \\
\text { from linguistic as from cultural differences. }\end{array}$} & Agree. & 18 & 72 \\
\hline & Neutral. & 5 & 20 \\
\hline & Disagree. & 2 & 8 \\
\hline \multirow{3}{*}{$\begin{array}{l}\text { 5. Foreign language teaching should enhance students' understanding of their own } \\
\text { cultural identity. }\end{array}$} & Agree. & 19 & 76 \\
\hline & Neutral. & 3 & 12 \\
\hline & Disagree. & 3 & 12 \\
\hline \multirow[t]{3}{*}{ 6. The cultural dimension in foreign language classes should be expanded. } & Agree. & 15 & 60 \\
\hline & Neutral. & 10 & 40 \\
\hline & Disagree. & 0 & 0 \\
\hline \multirow{3}{*}{$\begin{array}{l}\text { 7. All English-speaking countries' cultures are equally valid to be represented in an } \\
\text { English syllabus. }\end{array}$} & Agree. & 10 & 40 \\
\hline & Neutral. & 7 & 28 \\
\hline & Disagree. & 8 & 32 \\
\hline \multirow[t]{3}{*}{ 8. The study of culture in language classes can hinder progress in linguistic accuracy. } & Agree. & 4 & 16 \\
\hline & Neutral. & 3 & 12 \\
\hline & Disagree. & 18 & 72 \\
\hline \multirow{3}{*}{$\begin{array}{l}\text { 9. Learning about a foreign culture can change the student's attitude towards her own } \\
\text { culture. }\end{array}$} & Agree. & 10 & 40 \\
\hline & Neutral. & 9 & 36 \\
\hline & Disagree. & 6 & 24 \\
\hline \multirow{3}{*}{$\begin{array}{l}\text { 10. An emphasis on the study of foreign cultures can contribute to the student's loss of } \\
\text { cultural identity. }\end{array}$} & Agree. & 6 & 24 \\
\hline & Neutral. & 6 & 24 \\
\hline & Disagree. & 13 & 52 \\
\hline \multirow{3}{*}{$\begin{array}{l}\text { 11. The most important goal in learning about a foreign culture is to develop a critical } \\
\text { attitude towards both target and native cultures. (condition) }\end{array}$} & Agree. & 11 & 44 \\
\hline & Neutral. & 8 & 32 \\
\hline & Disagree. & 6 & 24 \\
\hline \multirow{3}{*}{$\begin{array}{l}\text { 12. The development of cultural awareness should be kept only for the most advanced } \\
\text { levels. }\end{array}$} & Agree. & 8 & 32 \\
\hline & Neutral. & 2 & 8 \\
\hline & Disagree. & 15 & 60 \\
\hline \multirow[t]{3}{*}{ 13. Teaching culture motivates students. } & Agree. & 20 & 80 \\
\hline & Neutral. & 4 & 16 \\
\hline & Disagree. & 1 & 4 \\
\hline \multirow[t]{3}{*}{ 14. Combining language and culture helps learners to improve their language skills. } & Agree. & 21 & 84 \\
\hline & Neutral. & 2 & 8 \\
\hline & Disagree. & 2 & 8 \\
\hline
\end{tabular}

As shown in Table 1, a significant proportion of approximately over two-thirds agree that teaching the EFL culture is as essential as teaching the language itself. Similarly, nearly two thirds of the teachers agree that culture and language can be integrated, and $60 \%$ of them think that the more students know about the target 
culture the more they become tolerant. Such results are compatible with Brown (2000) Kramsch (1998, cited in Eldin, 2015), Gonen \& Saglam's (2012) assertion that language and culture are inseparable. Moreover, they confirm the findings of Sercu \& Bandura (2005), Al-Fahadi (2006, cited in Al-Fahadi, 2012) and Gonen \& Saglam (2012) suggesting that teachers lean more towards what has been called creative performance as described by Chiu \& Cheng (2007) previously.

A significant proportion of the teachers $(70 \%)$ agree that most misunderstandings are caused equally by linguistic and cultural differences. Accordingly, $60 \%$ of them believe that the cultural dimension should be integrated more often in language classrooms. When it comes to the items of the questionnaire that investigated the benefits of such integration, the results reveal that a very large majority of approximately $75 \%$ of the teachers believe that teaching culture in EFL classrooms improves students' understanding of cultural identity. Similarly, a very large majority of teachers agree that integrating culture into language classrooms makes learning more motivating and improves learners' linguistic competence. Furthermore, over $70 \%$ disagree with those who argue that the study of culture restrain the obtainment of linguistic curacy. These results support the assertion that linguistic competence and cultural competence go hand in hand (Byram, Gribkova \& Starkey's, 2002 \& Samovar, Porter, \& Jain, 1981, cited in Thanasoulas, 2001). Shukri's (2014) argument that the use of cultural activities helps guiding the way students construct language and meaning.

When investigating teachers' perceptions of the conditions under which culture teaching is to be taught, the results show that $60 \%$ of the teachers disagree with the confiding cultural awareness to advanced learners and neglecting the beginners. Surprisingly, although EFL teachers in Saudi Arabia are affected by the Islam-phobic events as described by Al-Fahadi (2006, cited in Al-Fahadi, 2012), a proportion of $40 \%$ of the teachers agreed that all English-speaking countries are equally valid to be present in class, whereas almost only a third of them see the opposite.

When focusing on the effects of teaching culture in language classrooms, the results suggest the following. Although a proportion of $40 \%$ of the teachers agree that emphasizing the study of the target culture has the power of changing students' attitudes towards their own culture, over $50 \%$ of them disagree with the idea that such an emphasis leads to the loss of cultural identity. However, over $40 \%$ of the teachers think that the most essential goal in teaching and learning about a foreign culture should be to promote critical attitudes towards both native and foreign cultures.

\subsection{Question 2}

What kind of cultural competence do EFL seek to promote? Intercultural or multicultural competence?

As shown in the appendix, the last three items of the questionnaire were added in order to further investigate teachers' perceptions of the kind of cultural competence that should be promoted in EFL classrooms; given the fact that English has become a language spoken by people from different ethnicities and cultural backgrounds. Table 2 shows teachers' responses to these three items.

Table 2. Type of cultral comptence teachers perceieve as better in EFL contexts

\begin{tabular}{|c|c|c|c|}
\hline Items of the Questionnaire & $\mathrm{N}$ & $\mathrm{N}$ & $\%$ \\
\hline \multirow{3}{*}{$\begin{array}{l}\text { 15. When teaching the culture of the target language, it is the norms and values of } \\
\text { countries like the UK and the USA that should be targeted. }\end{array}$} & Agree. & 7 & 28 \\
\hline & Neutral. & 13 & 52 \\
\hline & Disagree. & 5 & 20 \\
\hline \multirow{3}{*}{$\begin{array}{l}\text { 16. The fact the English has become a Lingua Franca implies that instead of } \\
\text { teaching students the culture of a specific country, it is better to facilitate } \\
\text { multicultural competence. }\end{array}$} & Agree. & 20 & 80 \\
\hline & Neutral. & 5 & 20 \\
\hline & Disagree. & 0 & 0 \\
\hline \multirow{3}{*}{$\begin{array}{l}\text { 17. Instead of teaching students a specific culture, teachers should generally seek } \\
\text { to promote cultural tolerance among students. }\end{array}$} & Agree. & 21 & 84 \\
\hline & Neutral. & 4 & 16 \\
\hline & Disagree. & 0 & 0 \\
\hline
\end{tabular}

The results suggest that female EFL teachers are well aware of the consequences of the current state of English as described by Al-Fahadi (2012). As shown in Table 2, although over half of the teachers are uncertain of 
whether the norms and values of countries like the USA and the UK should be the ones to address or not, a very large majority of them agree that it is better to facilitate a more multicultural competence. Similarly, $84 \%$ of them believe that it is better to promote cultural tolerance instead of focusing on the aspects of one specific culture.

\section{Conclusion}

This study aimed at investigating how non-native EFL teachers perceive the integration of culture in EFL classrooms and how they view the different aspects of such integration. Moreover, given the fact that the status of English has changed from being a language associated with a specific culture to being one regarded as a lingua franca, the study also aimed at investigating teachers' perceptions of the type of cultural competence that should be promoted in class.

The results of the study revealed that non-native EFL teachers at the University of Jeddah view the study of culture in a positive manner, indicating that there is a growing awareness of the importance of facilitating students' cultural competence along with linguistic knowledge. Furthermore, teachers' responses to the questionnaire items showed that teachers' perceptions are in favor of the promotion of multicultural competence more than the intercultural one. Such results suggest that curriculum designers are required to allow the integration of more cultural elements into language classrooms and to train EFL teachers on how to teach culture in a pedagogical manner.

\section{References}

Alfahadi, A. (2012). Saudi teachers' views on appropriate cultural models for EFL textbooks: insights into TESOL teachers' management of global cultural flows and local realities in their teaching worlds (Doctoral dissertation, University of Exeter).

Blell, G., \& Doff, S. (2014). It takes more than two for this tango: Moving beyond the self/other-binary in teaching about culture in the global EFL-classroom. Zeitschrift für interkulturellen Fremdsprachenunterricht, 19(1).

Brown, H. D. (2000). Principles of Language Learning and Teaching (4th ed.). Longman.

Byram, M., Gribkova, B., \& Starkey, H. (2002). Developing the intercultural dimension in language teaching. $A$ practical introduction for teachers. Strasbourg: Council of Europe.

Chiu, C. Y., \& Cheng, S. Y. (2007). Toward a social psychology of culture and globalization: Some social cognitive consequences of activating two cultures simultaneously. Social and personality psychology compass, 1(1), 84-100. https://doi.org/10.1111/j.1751-9004.2007.00017.x

Damen, L. (1987). Culture learning: The fifth dimension in the language classroom. Reading, MA: Addison-Wesley

Dema, O., \& Moeller, A. K. (2012). Teaching culture in the 21st century language classroom.

Eldin, A. A. T. S. (2015). Teaching Culture in the Classroom to Arabic Language Students. International Education Studies, 8(2), 113. https://doi.org/10.5539/ies.v8n2p113

Gonen, S., \& Saglam, S. (2012). TEACHING CULTURE IN THE FL CLASSROOM: TEACHERS'PERSPECTIVES. International Journal of Global Education, l(3).

Grillo, R. D. (2003). Cultural essentialism and cultural anxiety. Anthropological Theory, 3(2), 157-173. https://doi.org/10.1177/1463499603003002002

Hesar, M. P., Konca, M. Y., \& Zarfsaz, E. (2012). Why and how to apply culture in an EFL classroom. In International Conference on Language, Medias and Culture IPEDR (Vol. 33, pp. 68 -72).

Mackey, A., \& Gass, S. M. (2005). Second language research: Methodology and design. Lawrence Erlbaum Associates, Inc., Publishers.

Sercu, L., \& Bandura, E. (2005). Foreign language teachers and intercultural competence: An international investigation (Vol. 10). Multilingual Matters.

Shukri, N. A. (2014). Second language writing and culture: Issues and challenges from the Saudi learners' perspective. Arab World English Journal, 5(3), 190-207.

Thanasoulas, D. (2001). The importance of teaching culture in the foreign language classroom. Radical pedagogy, 3(3), 1-25. 


\section{Appendix A}

\section{Questionnaire:}

Name:

Gender:

Are you a native speaker of English?

a. Yes.

b. No.

Job title:

Years of experience:

$\begin{array}{ll}\text { a. } & 0-1 \\ \text { b. } & 1-5 \\ \text { c. } & +5\end{array}$

\section{Please click on your answers to the items:}

1. In EFL classrooms, where I teach now, teaching culture is as important as teaching English.
a. Agree.
b. Neutral.
c. Disagree.

2. It is impossible to teach the foreign language and the foreign culture in an integrated way.
a. Agree.
b. Neutral.
c. Disagree.

3. The more students know about the foreign culture, the more tolerant they are.
a. Agree.
b. Neutral.
c. Disagree.

4. When speakers of different languages meet, misunderstandings arise equally often from linguistic as from cultural differences.
a. Agree.
b. Neutral.
c. Disagree.

5. Foreign language teaching should enhance students' understanding of their own cultural identity.
a. Agree.
b. Neutral.
c. Disagree.

6. The cultural dimension in foreign language classes should be expanded.
a. Agree.
b. Neutral.
c. Disagree.

7. All English-speaking countries' cultures are equally valid to be represented in an English syllabus.
a. Agree.
b. Neutral.
c. Disagree. 
8. The study of culture in language classes can hinder progress in linguistic accuracy.
a. Agree.
b. Neutral.
c. Disagree.

9. Learning about a foreign culture can change the student's attitude towards her own culture.
a. Agree.
b. Neutral.
c. Disagree.

10. An emphasis on the study of foreign cultures can contribute to the student's loss of cultural identity.
a. Agree.
b. Neutral.
c. Disagree.

11. The most important goal in learning about a foreign culture is to develop a critical attitude towards both target and native cultures.
a. Agree.
b. Neutral.
c. Disagree.

12. The development of cultural awareness should be kept only for the most advanced levels.
a. Agree.
b. Neutral.
c. Disagree.

13. Teaching culture motivates students.
a. Agree.
b. Neutral.
c. Disagree.

14. Combining language and culture helps learners to improve their language skills.
a. Agree.
b. Neutral.
c. Disagree.

15. When teaching the culture of the target language, it is the norms and values of countries like the UK and the USA that should be targeted.
a. Agree.
b. Neutral.
c. Disagree.

16. The fact the English has become a Lingua Franca (an international language) means that instead of teaching students the culture of a specific country, it is better to facilitate multicultural competence (one that represents a variety of cultures) in EFL classrooms.
a. Agree.
b. Neutral.
c. Disagree.

17. Instead of teaching students a specific culture, teachers should generally seek to promote cultural tolerance among students.

a. Agree. 
b. Neutral.

c. Disagree.

Thank you for contributing to knowledge :)

\section{Copyrights}

Copyright for this article is retained by the author(s), with first publication rights granted to the journal.

This is an open-access article distributed under the terms and conditions of the Creative Commons Attribution license (http://creativecommons.org/licenses/by/4.0/). 